\title{
Initial Expression and Endogenous Activation of NMDA Channels in Early Neocortical Development
}

\author{
Joseph J. LoTurco, Mark G. Blanton, and Arnold R. Kriegstein \\ Department of Neurology and Neurological Sciences, Stanford University School of Medicine, Stanford, California 94305
}

\begin{abstract}
We have made patch-clamp recordings from slices of fetal and postnatal rat neocortex in order to study the initial expression and activation of NMDA channels. Recordings from both whole cells and outside-out patches indicated that functional NMDA channels are expressed on neurons within the cortical plate, but not on younger cells within the ventricular zone. The NMDA channels on cortical plate neurons had a unitary conductance of approximately $40 \mathrm{pS}$, had a mean open time of approximately 6 msec, required glycine to open, and were blocked in a voltage-dependent manner by magnesium. These precocious channels were present before the appearance of functional synaptic activity, yet like NMDA channels in the mature neocortex, they were spontaneously activated by an agonist within brain slices. These results demonstrate that NMDA channels are initially expressed on neocortical neurons some time between the last mitotic division within the ventricular zone and completion of migration into the cortical plate. These early NMDA channels have properties characteristic of NMDA channels on more mature neurons and are similarly activated by an endogenous agonist in situ. Their early appearance and activation indicate that NMDA channels may play a role during early stages of cortical development.
\end{abstract}

Channels activated by glutamate and GABA are responsible for the majority of excitatory and inhibitory synaptic transmission in the mammalian neocortex (Watkins and Evans, 1981; Connors et al., 1988). Determining when these channels are expressed and activated during neocortical development is crucial to understanding the differentiation of cortical neurons.

Excitatory synaptic transmission in the mammalian neocortex is mediated by the activation of both NMDA and nonNMDA glutamate channels (Thomson, 1986; Jones and Baughman, 1988; Sutor and Hablitz, 1989; Lo Turco et al., 1990a). The non-NMDA channels mediate a fast, voltage-independent synaptic conductance, while the NMDA channels mediate a slower, voltage-dependent synaptic conductance (Mayer and Westbrook, 1988). In addition to their well-recognized role in synaptic transmission, NMDA channels are tonically activated in brain slices, and the resulting conductance regulates neuronal excitability (Sah et al., 1989; Lo Turco et al., 1990a). While

\footnotetext{
Received Aug. 14, 1990; revised Oct. 18, 1990; accepted Oct. 22, 1990.

This work was supported by NIH Grants NS12151 and NS21223 to A.R.K. J.J.L. was supported by a grant from the Pimley Foundation, and M.G.B., by Medical Scientist Training Program Training Grant GM07365. We wish to thank Istvan Mody and Douglas Coulter for helpful comments on the manuscript and John Avilla, Isabella Parada, and Andrea Cervenka for expert technical assistance.

Correspondence should be addressed to Joseph J. LoTurco at the above address. Copyright (C) 1991 Society for Neuroscience $0270-6474 / 91 / 110792-08 \$ 03.00 / 0$
}

much is known about NMDA channels on cultured neurons, NMDA channcls on developing ncocortical neurons have remained poorly characterized. Their time of expression, properties, and activation by endogenous agonist have not been previously investigated.

NMDA channels have been critically linked to plasticity in developing nervous systems (for review, see Constantine-Paton et al., 1990). When a neuron is depolarized sufficiently to relieve magnesium blockade of NMDA channels (Mayer et al., 1984; Nowak et al., 1984), calcium flows through the channels (McDermott et al., 1986; Jahr and Stevens, 1987) and affects neurite outgrowth (Pearce et al., 1987; Brewer and Cotman, 1989; Mattson and Kater, 1989) and synaptic connectivity (Cline et al., 1987; Kleinschmidt et al., 1987). Determining when similar mechanisms could operate during neocortical development requires identifying when functional NMDA channels first appear and are activated on neocortical neurons.

The mammalian neocortex is an ideal structure to study the developmental sequence of membrane channel expression, because neurons in different stages of development are segregated into defined regions or zones (Angevine and Sidman, 1961; Rakic, 1974; Luskin and Shatz, 1985). Specifically, in the developing rat neocortex, neuroblasts within the ventricular and subventricular zones undergo mitotic divisions between 12 and $21 \mathrm{~d}$ after fertilization (Hicks and D'Amato, 1968; Miller, 1988; Valverde et al., 1989). Newly postmitotic neurons then migrate out of the ventricular zone toward the pial surface, pass older cells that have previously migrated, and enter the cortical plate. The cortical plate first appears on embryonic day 15 (E15; Peters and Feldman, 1975), and migration into the cortical plate ends approximately $6 \mathrm{~d}$ after birth (P6; Miller, 1988).

Access to the physiological properties of neurons during the earliest stages of cortical development has been severely limited by technical difficulties. However, with the recent advance of tight-seal patch-clamp recordings from cells within brain slices (Blanton et al., 1989), a direct analysis of ion channel activity in relatively intact developing tissue is now possible. With this approach, we have characterized the initial expression, properties, and endogenous activation of NMDA channels during early neocortical development.

\section{Materials and Methods}

Preparation of brain slices. Gravid Sprague-Dawley rats (timed pregnancies, 16-19 d) or neonatal rats [day of birth (P0) to $12 \mathrm{~d}$ after birth (P12)] were anesthetized by an intraperitoneal injection of Nembutal. Brains were removed from the embryos (E16-19), embedded in 3\% agar $\left(35^{\circ} \mathrm{C}\right)$, and allowed to harden on ice. We found that embedding the fragile embryonic tissue in agar greatly improved the viability of the slices. Brains removed from postnatal animals were placed directly into ice-cold artificial cerebral spinal fluid (aCSF; see below) without em- 
bedding them in agar. Both postnatal and embedded embryonic brains were glued to a vibratome stage, and $400-\mu \mathrm{m}$ coronal slices were cut. Slices were then glued to the bottom of Petri dishes with plasma-thrombin clots, submerged in aCSF, and stored in a humidified oxygenated environment (Blanton et al., 1989).

Obtaining whole-cell and outside-out patch recordings. Whole-cell recordings (Hamill et al., 1981) were obtained from neurons in slices as previously described (Blanton et al., 1989). Briefly, electrodes (5-10 $\mathrm{M} \Omega$ ) were lowered into slices; a pulse of positive pressure was then applied to the back of the electrodes, and after pressure was released, they were slowly advanced through slices until a resistance increase was detected (10-50 M $\Omega$ ). A suction pulse was immediately applied to form tight seals (2-40 G $\Omega$ ), and additional suction was applied to rupture the underlying membrane. Nearly $80 \%$ of electrode penetrations resulted in successful wholc-ccll rccordings.

After data were collected from each whole-cell recording, outside-out patches were formed by slowly pulling the pipettes out of the brain slices. Approximately $50 \%$ of the time, an outside-out patch formed successfully. Pharmacological agents were then applied to each patch by rapidly moving the tip of the patch electrode between a system of perfusion pipettes similar to that described by Johnson and Ascher (1987).

All recordings were made with a List EPC-7 amplifier (Adams List). Currents were filtered at $1 \mathrm{kHz}(8$-pole Bessel, $3 \mathrm{~dB})$ and digitized at $10 \mathrm{kHz}$ for analysis. Data were collected and analyzed with either pCLAMP (Axon Instruments) or PAT (courtesy of John Dempster, University of Strathclyde). pCLAMP was used for generating continuous voltage ramps and for on-line leak subtraction of voltage-gated currents. PAT was used to analyze channel records and to fit histograms with gaussian and exponential functions. For channel analysis, openings were defined as a $50 \%$ deviation from baseline noise, and open-time and single-channel amplitude histograms were constructed. At least 1000 openings were used to construct histograms. Histograms were fit with exponential and gaussian functions by a least-squares method to determine the mean channel open times and unitary conductances, respectively.

Extracellular solutions. While in the recording chamber, slices were continuously superfused with aCSF. The aCSF contained $124 \mathrm{~mm} \mathrm{NaCl}$, $5 \mathrm{~mm} \mathrm{KCl}, 1.25 \mathrm{~mm} \mathrm{NaH}_{2} \mathrm{PO}_{4}, 2 \mathrm{~mm} \mathrm{MgCl}_{2}, 2 \mathrm{~mm} \mathrm{CaCl}, 26 \mathrm{~mm}$ $\mathrm{NaHCO}_{3}$, and $10 \mathrm{~mm}$ dextrose and was continuously bubbled with $95 \%$ $\mathrm{O}_{2}$ and $5 \% \mathrm{CO}_{2}$. In some experiments, $\mathrm{MgCl}_{2}$ was omitted from the medium. NMDA (Sigma), D-aminophosphonovalerate (D-APV; Cambridge Research Biochemicals), a selective NMDA receptor antagonist, and 7-chlorokynurenate (Tocris), an antagonist of the glycine receptor site on NMDA channels, were dissolved in aCSF and applied to whole cells by exchanging the bathing solution.

NMDA $(0.1-100 \mu \mathrm{M})$ was applied to outside-out patches, in the presence of $3 \mu \mathrm{M}$ glycine and in the absence of magnesium (except where noted). The perfusate was the same as the aCSF, except HEPES buffer (10 mM; $\mathrm{pH}, 7.3$ ) was substituted for the $\mathrm{NaHCO}_{3}$ and the solution was not bubbled with $95 \% \mathrm{O}_{2}$ and $5 \% \mathrm{CO}_{2}$.

Electrodes. Patch-clamp electrodes were pulled from thin-wall glass (World Precision Instruments) and filled with $130 \mathrm{~mm}$ Cs gluconate, 10 mM CsCl, $11 \mathrm{~mm}$ EGTA, $1 \mathrm{~mm} \mathrm{CaCl}, 1 \mathrm{~mm} \mathrm{MgCl}_{2}, 10 \mathrm{~mm}$ HEPES, and $1 \%$ biocytin (Sigma). The pH was adjusted to 7.2 with $\mathrm{CsOH}$, and the osmolarity was adjusted to approximately $280 \mathrm{mOsm}$. Osmolarity of the filling solution was found to be critical for the successful formation of seals in slices and was gencrally $10 \%$ lower than that of the bath solution. In some experiments, stainless-steel bipolar electrodes were placed within the tissue in several locations, and $200-\mu$ sec constant current pulses were delivered in an attempt to elicit synaptic currents.

Biocytin processing. All cells in this study were filled with biocytin by passive diffusion through the patch pipettes during whole-cell recording. After recording, slices were fixed overnight in $1.25 \%$ glutaraldehyde and $1 \%$ paraformaldehyde. Slices were then resectioned at $80-100 \mu \mathrm{m}$ and processed for biocytin (modified from Horikawa and Armstrong, 1988). The processing involved a $30-\mathrm{min}$ incubation in phosphate-buffered saline (PBS) containing $0.5 \% \mathrm{H}_{2} \mathrm{O}_{2}$ to saturate endogenous peroxidase, followed by a 45 -min incubation in PBS, $0.25 \%$ Triton $\mathrm{X}$, and $2 \% \mathrm{BSA}$. Following a wash in PBS alone, slices were incubated for $2 \mathrm{hr}$ in avidinHRP (Vector Labs) and 2\% BSA, rinsed in PBS, and then in tris-buffered saline (TBS). They were then reacted with diaminobenzidine and $\mathrm{H}_{2} \mathrm{O}_{2}$. Sections were thoroughly rinsed in TBS and incubated for $5 \mathrm{~min}$ in $\mathrm{Os}_{2} \mathrm{O}_{4}$ to intensify the staining. Sections were then mounted on slides, dehydrated, counterstained with cresyl violet, cleared in xylene, and coverslipped. This processing led to complete staining of filled cells,

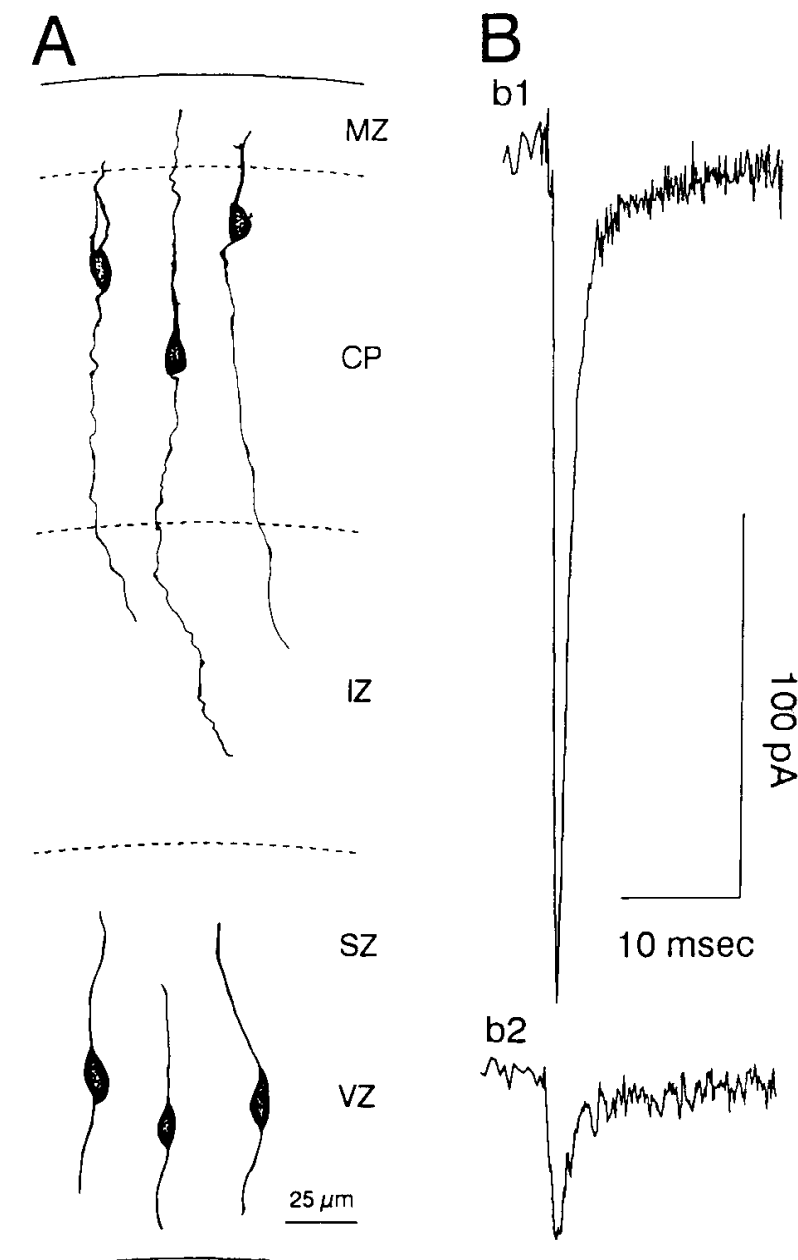

Figure 1. Biocytin-labeled cortical cells and fast inward currents recorded from cells in the ventricular zone and cortical plate. $A$, Camera lucida drawings of 6 neurons obtained from E1 7 and E1 8 embryos. The 3 cells in the ventricular zone $(V Z)$ had neuronal physiological properties and appear to be migrating neurons. The 3 cells in the cortical plate $(C P)$ also had neuronal properties. The full axons were not drawn for these cortical plate cells, but could be traced for several millimeters. $B$, Fast inward currents recorded from an E1 8 cortical plate neuron $(b l)$ and a ventricular zone cell $(b 2)$. Currents were leak subtracted $(\mathrm{P} / 10)$ by adding the currents generated by $109-\mathrm{mV}$ hyperpolarizing steps to the active current elicited by voltage steps from -90 to $0 \mathrm{mV} . M Z$, marginal zone; $I Z$, intermediate zone; $S Z$, subventricular zone.

with little or no background staining. Labeled cells were photographed and drawn by camera lucida.

\section{Results}

Recordings were made from 47 cells in the ventricular and subventricular zones of slices prepared from E16-19 embryos and 42 cells from the cortical plate of slices prepared from E1619 embryos and $\mathrm{P} 0-2$ neonates. In addition, 12 cells were recorded from layer II/III of slices prepared from P9-12 animals. We determined the morphology and verified the laminar location of all cells in this study by labeling each cell with biocytin during whole-cell recording.

In the ventricular and subventricular zones, 3 types of cells were encountered. One type $(n=10)$ had glial properties, namely, input resistances between 200 and $400 \mathrm{M} \Omega$, resting potentials between 70 and $80 \mathrm{mV}$, and no apparent voltage-activated currents. These cells were always in the ventricular zone and 


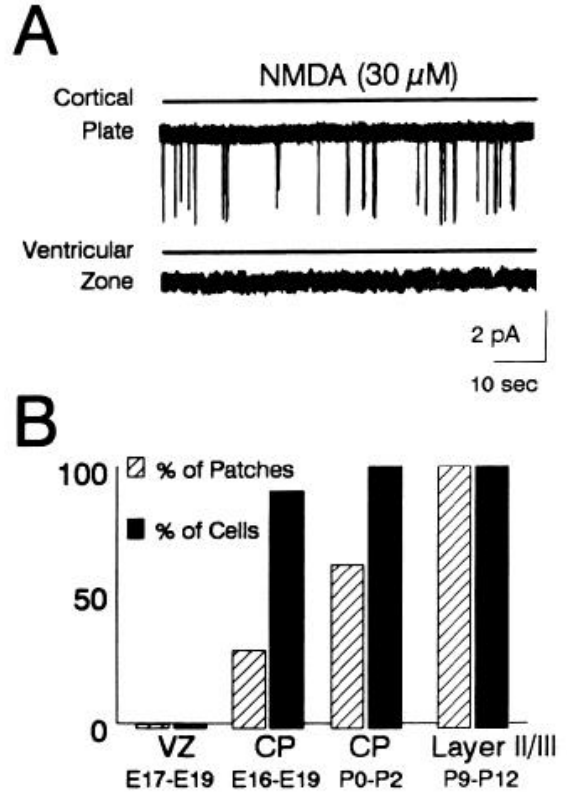

Figure 2. Functional NMDA channels are expressed in the cortical plate but not in the ventricular zone. $A$, Thirty-micromolar NMDA (bar) elicited channel activity in a patch from a cortical plate neuron (upper trace), but not in a patch from a bipolar ventricular zone neuron (lower trace). B, Summary of the percentage of patches and cells that responded to application of NMDA $(10-30 \mu \mathrm{M})$. Note that no cells or patches from the ventricular zone $(V Z)$ responded to NMDA, while nearly every cell in the cortical plate $(C P)$ responded. had morphologies characteristic of radial glia. Two other types of cells recorded in the ventricular and subventricular zones had neuronal properties. The most frequently encountered cells ( $n$ $=22$ ) had input resistances between 0.5 and $3 \mathrm{G} \Omega$, had resting potentials between -65 and $-40 \mathrm{mV}$, and generated fast inward currents (Fig. 1) upon the application of brief (30-msec) depolarizing voltage steps. These cells were encountered in the ventricular and subventricular zones and had the characteristic bipolar morphologies of migrating neurons (Fig. 1). The cells ( $n$ $=15$ ) encountered most frequently in the subventricular zone of older embryonic slices had neuronal physiological properties like the migrating neurons but had multipolar morphologies.

All cells in the cortical plate generated fast inward currents (Fig. 1) that reversed near the sodium equilibrium potential and were blocked by tetrodotoxin (TTX). In addition, cortical plate neurons had input resistances between $800 \mathrm{M} \Omega$ and $3 \mathrm{G} \Omega$ and resting potentials between -65 and $-35 \mathrm{mV}$. Cells with glial properties were never encountered when electrodes were targeted to the cortical plate.

\section{NMDA channels are expressed in the cortical plate}

NMDA channels have several properties unique to this class of glutamate-activated channel. First, they are blocked in a voltage-dependent manner by magnesium ions (Mayer et al., 1984; Nowak et al., 1984), and second, they will open more frequently in the presence of glycine (Johnson and Ascher, 1987; Kleckner and Dingledine, 1988). No NMDA channel activity was detected in either cells or excised patches from the ventricular and subventricular zones (Fig. 2). In sharp contrast, both cells and membrane patches excised from cells within the cortical plate
A

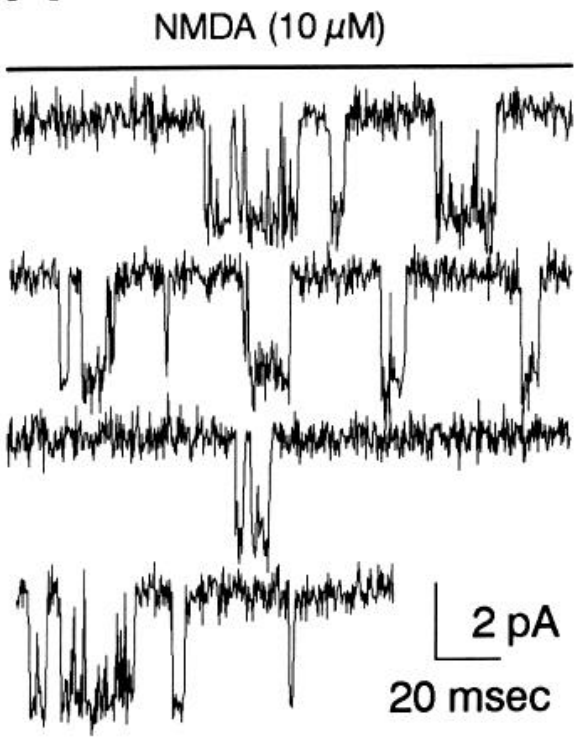

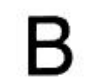

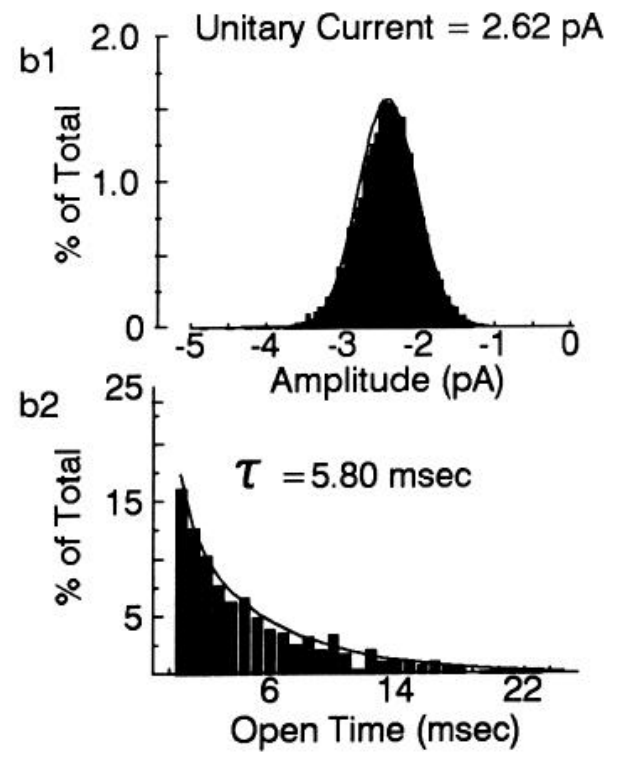

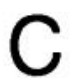

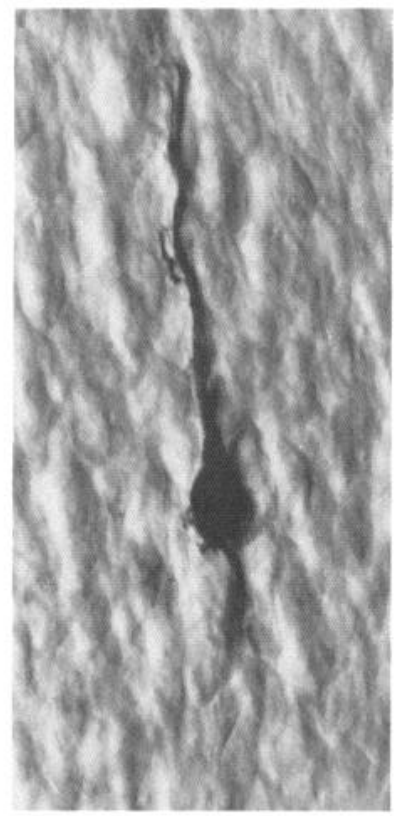

Figure 3. Biophysical properties of NMDA channels expressed on an E18 cortical plate neuron. $A$, Channels elicited by the application of $10 \mu \mathrm{M}$ NMDA in the presence of $3 \mu \mathrm{m}$ glycine and absence of magnesium. $B$. Histograms of current amplitude and open time duration of channel events recorded from the same patch as in $A$. $C$, Photograph of the cortical plate cell that was filled with biocytin before the patch analyzed in $A$ and $B$ was pulled off the cell. Magnification, $1000 \times$. 

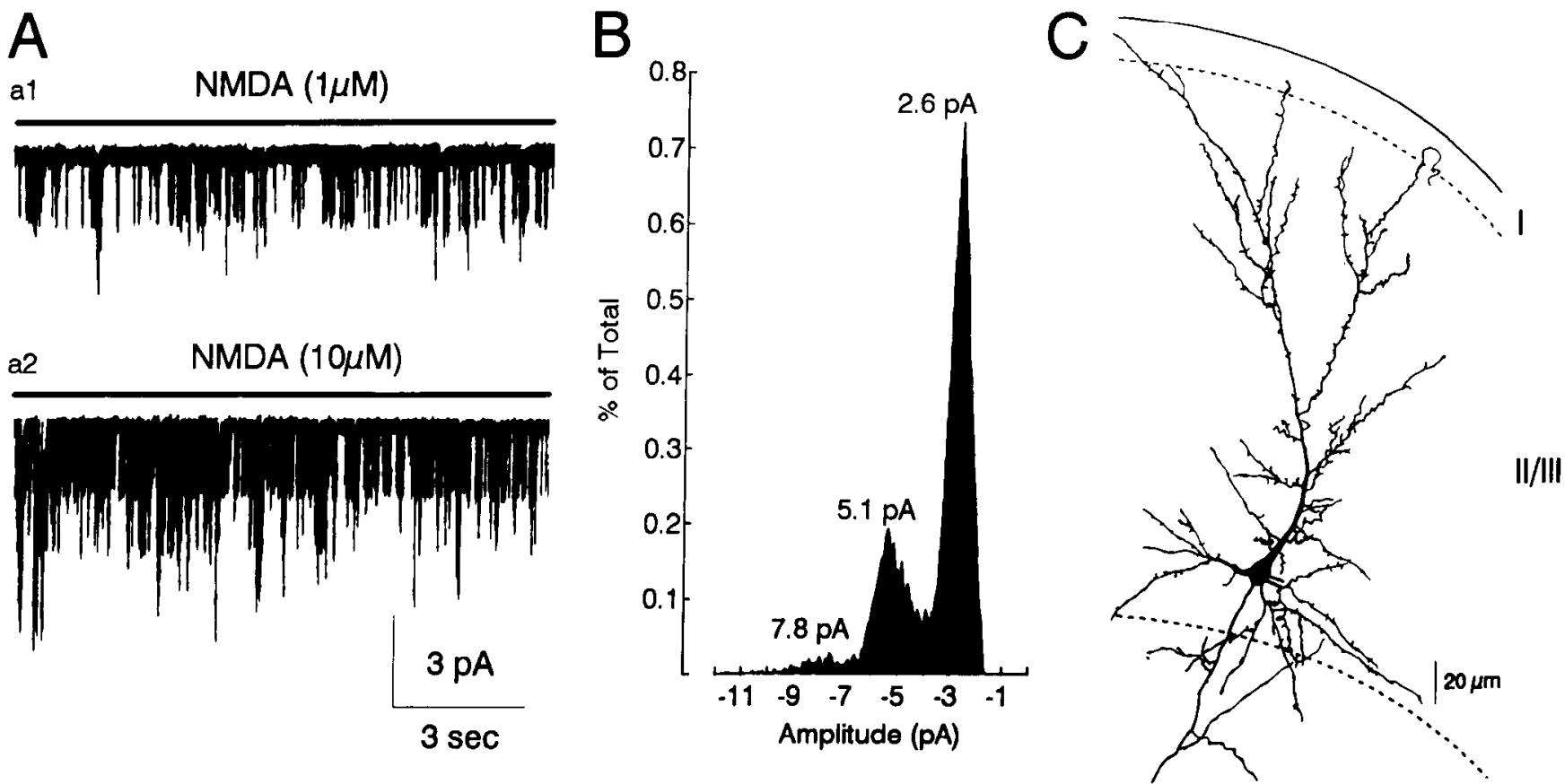

Figure 4. NMDA channels recorded from a pyramidal neuron in layer II/III. $A$, Channels elicited by the application of $1 \mu \mathrm{M}(a I)$ and $10 \mu \mathrm{M}$ NMDA $(a 2)$ to a patch obtained from a P12 layer II/III pyramidal cell. $B$, Histogram of currents recorded from the patch depicted in $A$ to $10 \mu \mathrm{M}$ NMDA. The 3 peaks in the histogram indicate a unitary current of $2.6 \mathrm{pA}$. $C$, A drawing of the cell from which the patch analyzed in $A$ and $B$ was obtained.

responded to the application of NMDA $(1-100 \mu \mathrm{M})$. To address what percentage of cells in the cortical plate actually had NMDA channels, $30 \mu \mathrm{M}$ NMDA was bath applied to cells recorded in the whole-cell configuration. Nearly every embryonic cortical plate cell $(15$ of $17 ; 88 \%)$ responded with an inward current (14 $\pm 4 \mathrm{pA}$, mean $\pm \mathrm{SD}$ ) when NMDA was applied with the membrane held at $-25 \mathrm{mV}$ in $2 \mathrm{mM}$ magnesium (see Figs. $2 B, 6$ ). The currents elicited by NMDA in every cell showed voltage dependence characteristic of NMDA channels (see below).

NMDA channel activity elicited by $10-100 \mu \mathrm{M}$ NMDA was detected in $25 \%$ ( 4 of 12) of membrane patches obtained from embryonic cortical plate cells. The percentage of patches with NMDA channel activity increased to $70 \%(7$ of 10$)$ in neonatal cortical plate cells (P0-2) and to $100 \%$ (7 of 7 ) in P9-12 layer II/III cells. This increase in the percentage of membrane patches containing NMDA channels suggests that the somatic density of NMDA channels is lower on embryonic cells than on older postnatal cells.

\section{Biophysical properties of NMDA channels in the cortical plate}

In the absence of magnesium, channels from patches of cortical plate neurons had a unitary conductance of $38 \pm 2 \mathrm{pS}$ and a mean channel open time of $5.6 \pm 0.4 \mathrm{msec}$. These values are similar to those obtained for channels on cultured neurons (Jahr and Stevens, 1987; Ascher et al., 1988). Figure 3 shows an example of NMDA channel activity recorded from a patch excised from the E18 cortical plate cell illustrated in the photograph (Fig. 3C).

In patches obtained from more mature neurons (P9-12), application of 10-100 $\mu \mathrm{M}$ NMDA, the same concentrations used to activate channels on cortical plate cells, characteristically activated too many channels for unitary events to be resolved. Single channel events from more mature neurons could be re- solved if much lower concentrations of NMDA $(0.1 \mu \mathrm{M})$ were applied to patches. These channels had a conductance of $37 \pm$ $3 \mathrm{pS}(n=5)$ and an open time of $4.9 \pm 0.6 \mathrm{msec}(n=5)$. In a fortuitous patch from a P1 2 neuron (Fig. 4), only a few channels were activated by $10 \mu \mathrm{M}$ NMDA, allowing a direct comparison with embryonic channels exposed to the same concentration of NMDA. The unitary conductance of channels in this patch was $36 \mathrm{pS}$, nearly the same as the conductance of NMDA channels on much less mature cortical plate neurons.

\section{NMDA channels require glycine and are blocked by magnesium}

NMDA channels described in other systems are blocked in a voltage-dependent manner by magnesium ions (Mayer et al., 1984; Nowak et al., 1984) and open more frequently in the presence of glycine (Johnson and Ascher, 1987; Kleckner and Dingledine, 1988). Figure 5 illustrates these same properties for NMDA channels expressed on cortical plate neurons. These early expressed channels opened less frequently in the absence of glycine (Fig. 5; $n=5$ ). These channels were largely blocked by $100 \mu \mathrm{M} \mathrm{Mg}^{2+}$ when the membrane potential was held at -70 $\mathrm{mV}$, but this $\mathrm{Mg}^{2+}$ blockade was relieved when the membrane potential was depolarized to $-25 \mathrm{mV}$ ( $n=5$; Fig. 5).

In order to investigate the voltage dependence of NMDAinduced conductances in the presence of magnesium, we recorded from whole cells and applied voltage ramps from +40 to $-100 \mathrm{mV}$ before and after the application of $30 \mu \mathrm{M}$ NMD $\Lambda$. Currents elicited by the voltage ramps were then subtracted to yield the current-voltage relationship for currents evoked by NMDA. This relationship, shown in Figure $6 B$, illustrates the marked nonlinear voltage dependence and region of negative slope conductance characteristic of NMDA currents. The current is almost completely blocked at $-100 \mathrm{mV}$, peaks at -25 


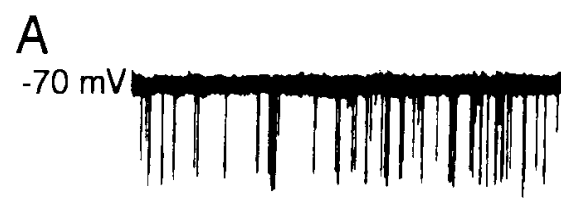

B

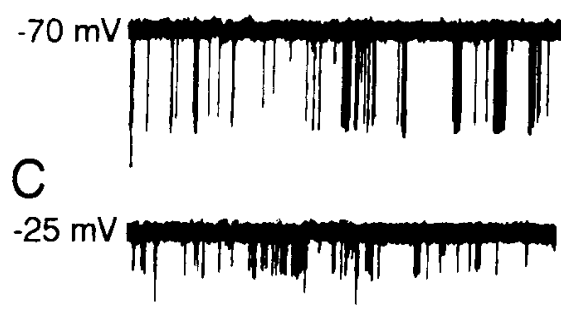

(-) Glycine
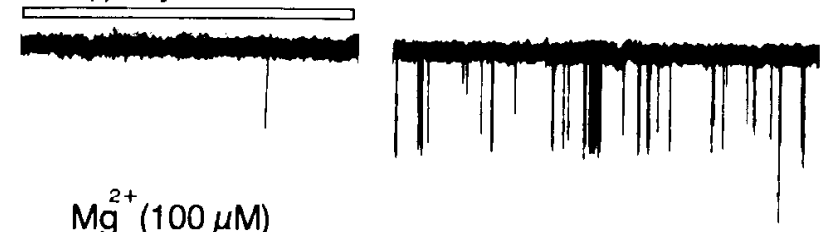

$\mathrm{Mg}^{2+}(100 \mu \mathrm{M})$
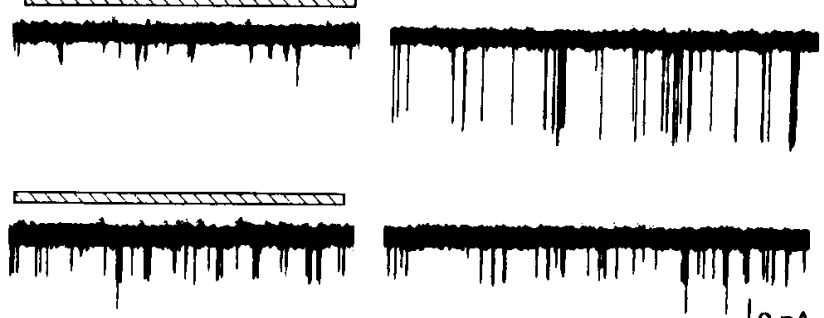
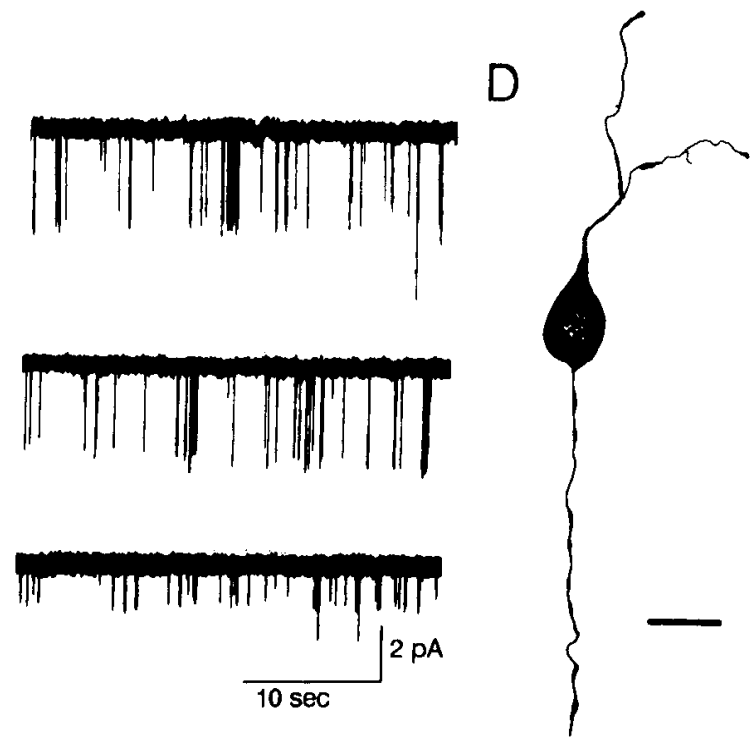

Figure 5. NMDA channels on cortical plate cells require glycine to open and are blocked by magnesium in a voltage-dependent manner. The patch depicted in this figure was obtained from a P0 cortical plate cell and was exposed to $10 \mu \mathrm{M}$ NMDA. $A$, When $3 \mu \mathrm{M}$ glycine was removed (middle) the frequency of channel openings decreased. $B$, When magnesium $(100 \mu \mathrm{M})$ was applied with the patch held at $-70 \mathrm{mV}$, the apparent channel conductance was greatly decreased; however, as shown in $C$, when the same procedure was repeated with the patch held at $-25 \mathrm{mV}$, this blockade was not observed. $D$, Drawing of the cell from which the outside-out patch was obtained. Scale bar, $10 \mu \mathrm{m}$.

$\mathrm{mV}$, and reverses near $0 \mathrm{mV}$. Recordings from all cortical plate cells tested ( 12 of 12 ) revealed the same nonlinear voltage dependence. These results, together with the single-channel data, indicatc that NMDA channcls cxpressed on cortical plate neurons show marked voltage dependence that results from blockade of channels by magnesium ions.

\section{Embryonic NMDA channels are activated by ambient agonist}

Knowing that NMDA channels were present on neurons in the cortical plate, we asked if these channels were activated by endogenously released excitatory amino acids within embryonic tissue. First, we attempted to evoke synaptic currents by stimulating several sites proximal to and surrounding the whole-cell recording sites. Consistent with the lack of synaptic specializations on cortical plate neurons (Peters and Feldman, 1975; Blue and Parnavelas, 1983), we were unable to evoke synaptic cur- rents in any of the 10 cells tested. Such stimulation in more mature cortex has been shown to evoke clear excitatory synaptic currents (Lo Turco et al., 1990b). Similarly, spontaneous synaptic currents, while apparent in more mature tissuc, were absent from all 42 cortical plate neurons in this study.

In slices of adult cortex, we have previously reported that NMDA channels are spontaneously activated by endogenous agonist (Lo Turco et al., 1990a). NMDA channels on cortical plate neurons are similarly activated in the absence of any exogenous source of NMDA receptor agonist. Spontaneous currents observed in whole-cell recordings from cortical plate cells were antagonized by D-APV (50-150 $\mu \mathrm{M} ; n=15)$, blocked by magnesium $(0.5$ and $2 \mathrm{mM})$ in a voltage-dependent manner $(n$ $=21)$, and reduced in frequency by 7 -chlorokynurenate ( $30 \mu \mathrm{M}$; $n=3$ ), an antagonist of the glycine site on NMDA receptors (Fig. 7).
Figure 6 . Whole-cell currents elicited by the application of $30 \mu \mathrm{M}$ NMDA reveal the voltage dependence of NMDA currents on cortical plate neurons. This cell was recorded from an E19 cortical plate neuron in the presence of $2 \mathrm{~mm}$ magnesium. $A$, Bath application of NMDA elicited an inward current with the cell held at $-25 \mathrm{mV}$. $B$, Voltage ramps from +30 to $-100 \mathrm{mV}$ were applied before and after the application of NMDA. The resulting currents were then subtracted [(current in the presence of NMDA) - (current in the absence of NMDA)], and the difference is plotted as a current-voltage relationship.

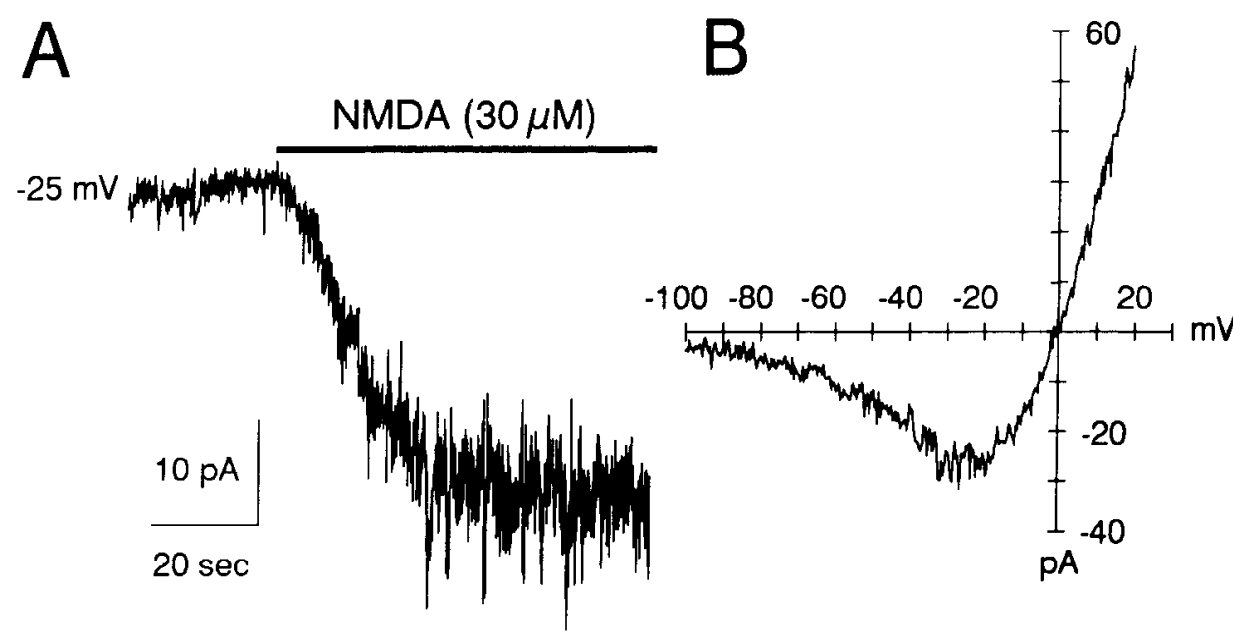




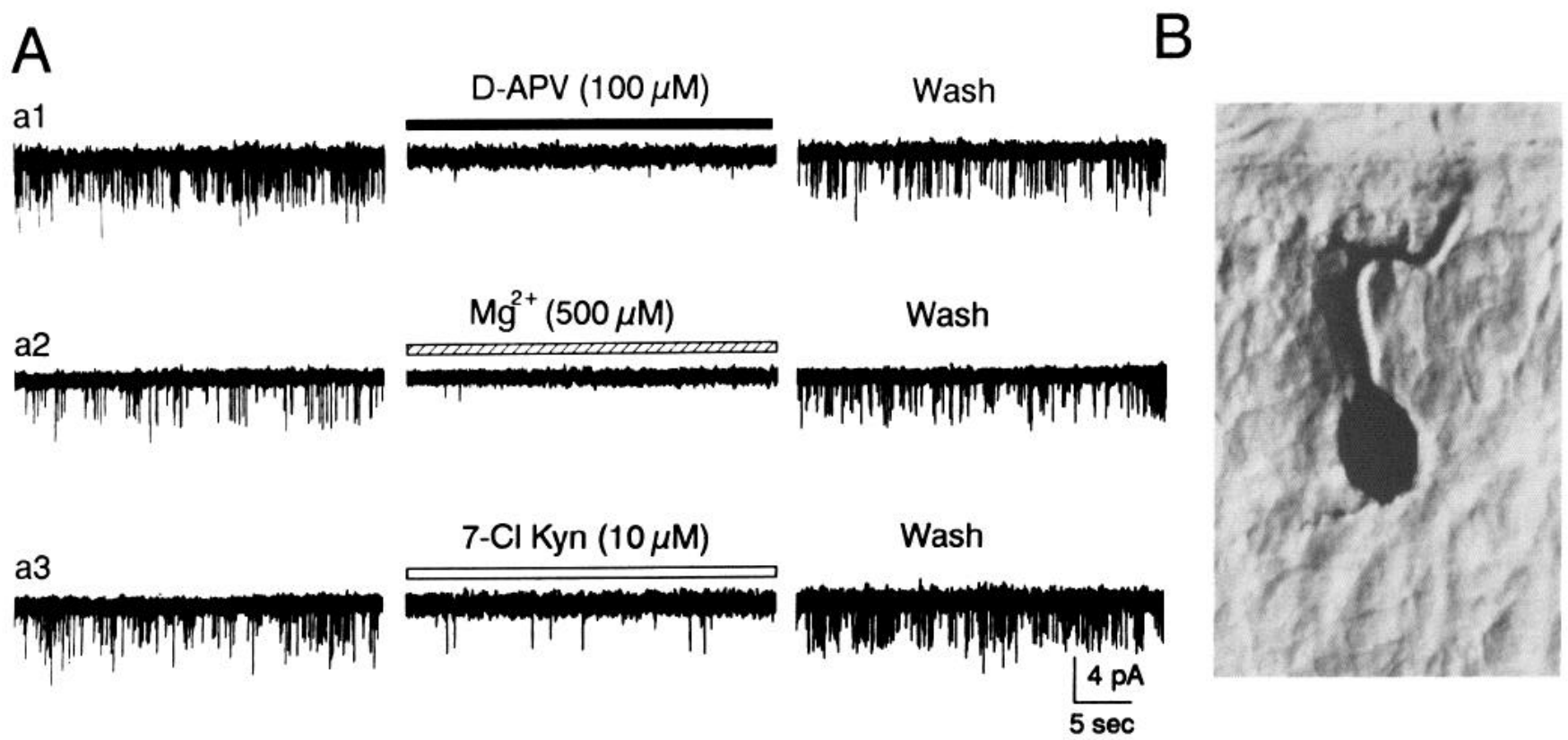

Figure 7. Pharmacology of endogenously activated NMDA currents recorded in whole-cell configuration. The cell depicted in this figure is from the cortical plate of an E16 embryo. A, Pharmacology of current fluctuations recorded from a cell held at $-70 \mathrm{mV}$ in the absence of magnesium. Bath application of D-APV antagonized spontaneous currents $(\mathrm{al})$ as did magnesium $(\mathrm{a} 2)$. Application of 7-chlorokynurenate (7-Cl $\mathrm{Kyn}$; $\mathrm{a} 3$ ) decreased the frequency of current fluctuations. $B$, Photograph of the cell recorded from in $A$. Magnification, 1500x.

Because the input impedances of embryonic cells were extremely high (1-3 G $\Omega$ ), the spontaneous NMDA current fluctuations could be resolved as single-channel events (Fig. $8 A$ ). The shape of these events, their rapid rise and fall, indicate that they were generated electrotonically close to the recording electrode. The conductance of these channel events in whole cells ( $35 \pm 2 \mathrm{pS} ; n=8$ ) was similar to the conductance of NMDA channels measured from excised patches (Fig. $8 B, C$ ). This agreement in channel conductance provides further evidence that the spontaneously activated channels on cortical plate neurons are in fact NMDA channels. Such current fluctuations were observed in 21 of 24 cells tested, nearly the same percentage of cells that responded to bath application of NMDA. These results show that, even before the development of functional synaptic activity, NMDA channels on neocortical neurons are activated by endogenous excitatory amino acids.

\section{Discussion}

In the developing neocortex, functional NMDA channels are first expressed on neurons within the cortical plate, and these

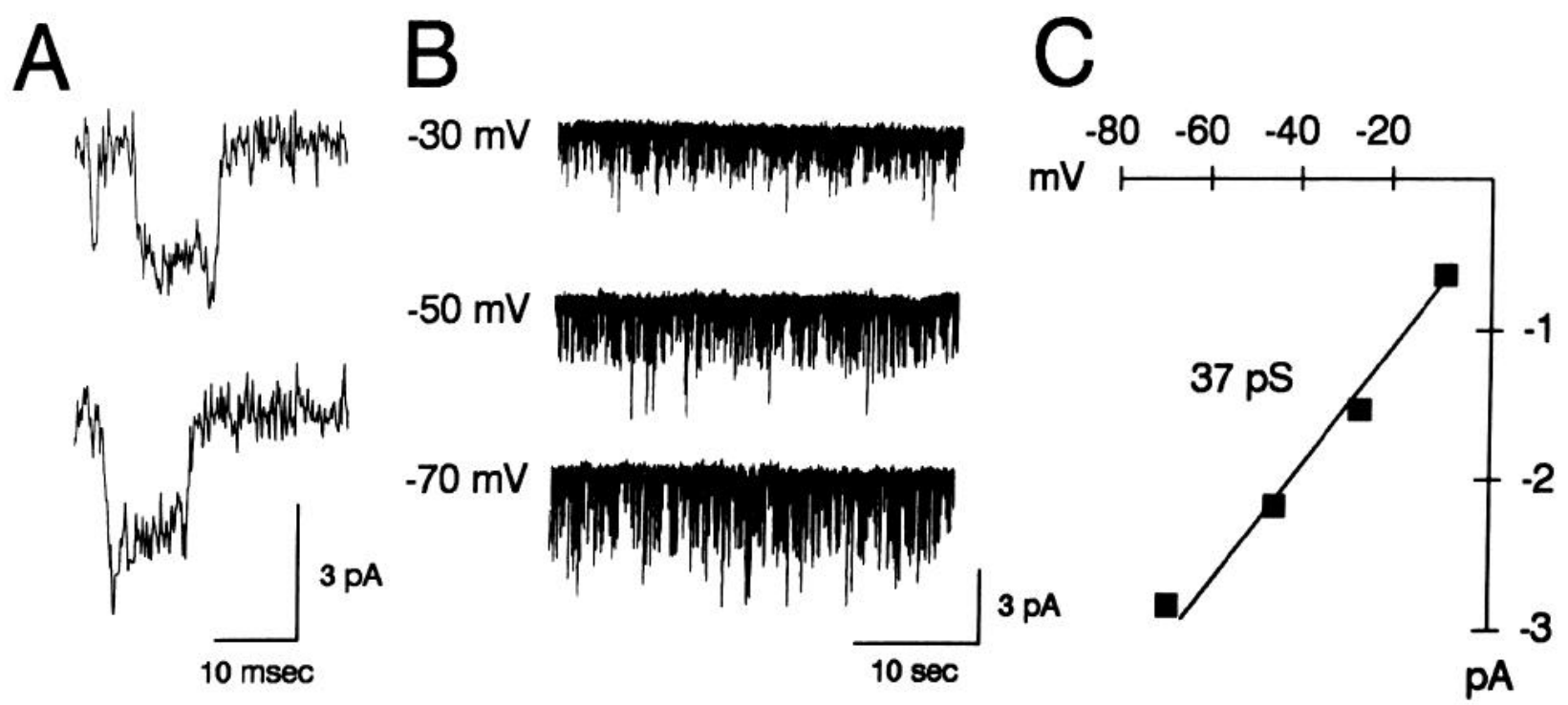

Figure 8. Endogenously activated NMDA channels recorded in whole-cell configuration can be resolved as channel events. The recording depicted in this figure was obtained from an E1 8 cortical plate cell in the absence of magnesium. $A$, Single NMDA channel events recorded from a cortical plate cell. $B$, Channel currents at different holding potentials. $C$, Plot of the unitary channel currents as a function of membrane potential. The line was fit by linear regression and indicates a unitary conductance of $37 \mathrm{pS}$. 
channels have properties similar to those previously reported for NMDA channels on cultured neurons (Jahr and Stevens, 1987; Ascher et al., 1988; Mayer and Westbrook, 1988). Specifically, they have a single-channel conductance of approximately $40 \mathrm{pS}$, have a predominant open time of $6 \mathrm{msec}$, require glycine to open, and are blocked by magnesium ions in a voltagedependent manner. Functional NMDA channels appear on cortical neurons before synapses form and are activated by endogenous transmitter within embryonic brain slices.

The timing of expression for functional NMDA channels is different than for 3 other ion channels we have investigated. Migrating neurons in the ventricular zone do not express NMDA channels until they reach the cortical plate, but they do express voltage-gated sodium channels, potassium channels, and GABAactivated channels while still in the ventricular zone (Lo Turco et al., 1990b). This suggests that initial expression of NMDA channels and other neuronal channels are under differential control. Temporal differences in the initial expression of neuronal channels has also been described for amphibian spinal cord neurons (Bixby and Spitzer, 1982; Harris et al., 1988).

Nencortical neurons begin to express functional NMDA channels near the end of their migration, and at the same time they begin to elaborate dendritic processes. This coincidence may indicate a mechanistic connection between NMDA channel expression, termination of migration, and dendritic elaboration. Like mammalian cortical neurons, embryonic turtle cortical neurons initially express NMDA channels coincident with neurite elaboration; however, unlike mammalian cortical neurons, these events begin within the ventricular zone (Blanton et al., 1990). Because turtle neurons migrate only a short distance from the ventricular zone (Goffinet et al., 1986), it is possible that both neurite elaboration and expression of NMDA channels are triggered by signals generated near the end of migration.

Previous studies of NMDA channels on immature neurons in amphibians (Sands and Barish, 1989) and reptiles (Blanton et al., 1990) have shown that initially expressed NMDA channels are blocked by magnesium in a voltage-dependent manner. Similarly, our results demonstrate that the first NMDA channels expressed on mammalian neocortical neurons are blocked by magnesium in a voltage-dependent manner. NMDA channels on immature hippocampal CA3 neurons, however, are thought to show less consistent voltage dependence (Ben-Ari et al., 1988). The voltage dependence of NMDA channels is of particular theoretical importance because it has been proposed as a mechanism for regulating activity-dependent plasticity in developing nervous systems (Constantine-Paton et al., 1990). Activity dependence results from the requirement of depolarization to remove magnesium blockade from NMDA channels. Once unblocked, calcium ions can flow through NMDA channels into developing cells and could initiate growth processes (Pearce et al., 1987; Brewer and Cotman, 1989).

We have shown not only that NMDA channels are expressed on neurons within the cortical plate, but also that they are activated by an endogenous agonist within embryonic tissue. The identity of this agonist is unknown. Glutamate is an attractive candidate because it is a very potent activator of NMDA channels (Patneau and Mayer, 1990). In fact, the affinity is high enough (Patneau and Mayer, 1990) that levels of glutamate within cerebral spinal fluid would be sufficient to activate NMDA channels. Fluctuations in levels of circulating glutamate could potentially influence early cortical differentiation by interacting with nonsynaptic NMDA channels on cortical plate neurons.
The source of agonist that spontaneously activates NMDA channels on embryonic neurons within slices is also unknown. Although we were unable to detect functional synaptic activity in cortical plate neurons, and though ultrastructural studies show that there are no synaptic contacts within the cortical plate (Peters and Feldman, 1975; Blue and Parnavelas, 1983), it is possible that glutamate released from immature synapses in the marginal (Peters and Feldman, 1975) and intermediate zones (Molliver et al., 1973; Friauf et al., 1990) could diffuse into the cortical plate and activate NMDA channels. Gradients that may result from such diffusion could help to direct bipolar extension of dendrites in developing cortical plate ncurons (Rakic, 1975).

Our results show that NMDA channels are expressed and activated on neurons within the cortical plate before both the formation of synapses and extensive elaboration of dendrites. In other systems, activation of NMDA channels has been shown to influence elaboration of dendrites (Pearce et al., 1987; Brewer and Cotman, 1989) and stabilization and segregation of afferents (Cline et al., 1987; Kleinschmidt et al., 1987). Long-term potentiation (LTP), which is similarly dependent upon postsynaptic activation of NMDA channels (Collingridge et al., 1983), has been associated with changes in both dendritic spine morphology (Desmond and Levy, 1986) and presynaptic transmission (Malinow and Tsien, 1990). Perhaps during early cortical development, activation of NMDA channels triggers postsynaptic mechanisms, like those initiated during LTP, that have effects on both postsynaptic and presynaptic development. A unifying mechanism may exist throughout development that links NMDA receptor activation to changes in dendritic morphology and afferent connectivity.

\section{References}

Angevine J, Sidman RL (1961) Autoradiographic study of cell migration during histogenesis of cerebral cortex in the mouse. Nature 192 766-768.

Ascher P, Bregestovski P, Nowak L (1988) $N$-methyl-D-aspartateactivated channels of mouse central neurones in magnesium-free solutions. J Physiol (Lond) 399:207-226.

Ben-Ari Y, Cherubini E, Krnjevic K (1988) Changes in voltage dependence of NMDA currents during development. Neurosci Lett 94 88-92.

Bixby JI, Spitzer NC. (1982) The appearance and development of chemosensitivity in Rohon-Beard neurones of Xenopus spinal cord. J Physiol (Lond) 330:505-536.

Blanton MG, Lo Turco JJ, Kricgstcin AR (1989) Whole-cell recording from neurons in slices of reptilian and mammalian cerebral cortex. J Neurosci Meth 30:203-210.

Blanton MG, Lo Turco JJ, Kriegstein AR (1990) Endogenous neurotransmitter activates $N$-methyl-D-aspartate (NMDA) receptors on differentiating neurons in embryonic cortex. Proc Natl Acad Sci USA 87:8027-8030.

Blue ME, Parnavelas JG (1983) The formation and maturation of synapses in the visual cortex of rat. II. Quantitative analysis. J Neurocytol 12:697-712.

Brewer GL, Cotman CW (1989) NMDA receptor regulation of neuronal morphology in cultured hippocampal neurons. Neurosci Lett 99:268-273.

Cline HT, Debski EA, Constantine-Paton M (1987) $N$-methyl-D-aspartate receptor antagonist desegregates cyc-spccific stripes. Proc Natl Acad Sci USA 84:4342-4345.

Collingridge GL, Kehl SJ, McLennan H (1983) Excitatory amino acids in synaptic transmission in the Schaffer-collateral commissural pathway of the rat hippocampus. J Physiol (Lond) 334:33-46.

Connors BW, Malenka RC, Silva LR (1988) Two inhibitory postsynaptic potentials, and GABAa and GABAb receptor mediated responses in neocortex of rat and cat. J Physiol (Lond) 406:443-468.

Constantine-Paton M, Cline HT, Debski E (1990) Patterned activity, 
synaptic convergence and the NMDA receptor in developing visual pathways. Annu Rev Neurosci 13: in press.

Desmond NL, Levy WB (1986) Changes in numerical density of synaptic contacts with long-term potentiation in the hippocampal dentate gyrus. J Comp Neurol 253:466-475.

Friauf E, McConnell SK, Shatz CJ (1990) Functional synaptic circuits in the subplate during fetal and early postnatal development of cat visual cortex. J Neurosci 10:2601-2613.

Goffinet AM, Daumerie CH, I angerwerf B, Pieau C (1986) Neurogenesis in reptilian cortical structures: ${ }^{3} \mathrm{H}$-thymidine autoradiographic analysis. J Comp Neurol 243:106-116.

Hamill OP, Marty A, Neher E, Sakmann B, Sigworth FJ (1981) Improved patch-clamp techniques for high-resolution current recording from cells and cell-free membrane patches. Pfluegers Arch 391:85100.

Harris GL, Henderson LP, Spitzer NC (1988) Changes in densities and kinetics of delayed rectifier potassium channels during neuronal differentiation. Neuron 1:739-750.

Hicks SP, D'Amato CJ (1968) Cell migration to the isocortex in the rat. Anat Rec 160:619-634.

Horikawa K, Armstrong WE (1988) A versatile means of intracellular labelling: injection of biocytin and its detection with avidin conjugates. J Neurosci Meth 25:1-11

Jahr CE, Stevens CF (1987) Glutamate activates multiple single channel conductances in hippocampal neurons. Nature 325:522-525.

Johnson JW, Ascher P (1987) Glycine potentiates the NMDA response in cultured mouse brain neurons. Nature 325:529-531.

Jones KA, Baughman RW (1988) NMDA and non-NMDA components of excitatory synaptic potentials recorded from cells in layer $V$ of rat visual cortex. J Neurosci 8:3522-3534.

Kleckner NW, Dingledine R (1988) Requirements for glycine in activation of NMDA-receptors expressed in Xenopus oocytes. Science 241:835-837.

Kleinschmidt A, Bear MF, Singer W (1987) Blockade of NMDA receptors disrupts experience dependent plasticity of kitten striate cortex. Science 238:355-358.

Lo Turco JJ, Mody I, Kriegstein AR (1990a) Differential activation of glutamate receptors by spontaneously released transmitter in slices of neocortex. Neurosci Lett 114:265-271.

Lo Turco JJ, Blanton MG, Kriegstein AR (1990b) Appearance of functional voltage and amino acid gated channels on embryonic neocortical neurons. Soc Neurosci Abstr 16:797.

Luskin MB, Shatz CJ (1985) Studies of the earliest generated cells of the cat's visual cortex: cogeneration of subplate and marginal zone. Neuroscience 5:1062-1075.

Malinow R, Tsien RW (1990) Presynaptic enhancement shown by whole-cell recordings of long-term potentiation in hippocampal slices. Nature 346:177-180.

Mattson MP, Kater SB (1989) Excitatory and inhibitory neurotransmitters in the generation and degeneration of hippocampal neuroarchitecture. Brain Res 478:337-348.
Mayer ML, Westbrook GL (1988) The physiology of excitatory amino acids in the vertebrate central nervous system. Prog Neurobiol 28: 197-276.

Mayer ML, Westbrook GL, Guthrie PB (1984) Voltage-dependent block by magnesium of NMDA responses in spinal cord neurones. Nature 309:261-263.

McDermott AB, Mayer ML, Westbrook GL, Smith SJ, Barker JL (1986) NMDA-receptor activation increases cytoplasmic calcium concentration in cultured spinal cord neurons. Nature 321:519-522.

Miller MW (1988) Development of projection and local circuit neurons in neocortex. In: Cerebral cortex, Vol 7 (Peters A, Jones EG, eds), pp 133-175. New York: Plenum.

Molliver ME, Kostovic I, Van der Loos H (1973) The development of synapses in the cerebral cortex of the human fetus. Brain Res 50: 403-407.

Nowak L, Bregestovski P, Ascher P, Herbert A, Prochiantz A (1984) Magnesium gates glutamate activated channels in mouse central neurones. Nature 307:462-465.

Patneau DK, Mayer ML (1990) Structure-activity relationships for amino acid transmitter candidates acting at $N$-methyl-D-aspartate and quisqualate receptors. J Neurosci 10:2385-2399.

Pearce IA, Cambray-Deakin MA, Burgoyne RD (1987) Glutamate acting on NMDA receptors stimulates neurite outgrowth from cerebellar granule cells. FEBS Lett 223:143-147.

Peters A, Feldman M (1975) The cortical plate and molecular layer of the late rat fetus. J Anat Embryol 141:3-37.

Rakic P (1974) Neurons in the rhesus monkey visual cortex: systematic relation between time of origin and eventual disposition. Science 183: 425-427.

Rakic P (1975) Role of cell interaction in development of dendritic patterns. In: Advances in neurology, Vol 12, Physiology and pathology of dendrites (Kreutzberg GW, ed), pp 117-134. New York: Raven.

Sah P, Hestrin S, Nicoll RA (1989) Tonic activation of NMDA receptors by ambient glutamate enhances excitability of neurons. Science 246:815-818.

Sands SB, Barish ME (1989) A quantitative description of excitatory amino acid neurotransmitter responses on cultured embryonic Xenopus spinal neurons. Brain Res 502:375-386.

Sutor B, Hablitz JJ (1989) EPSPs in rat neocortical neurons in vitro: I. Electrophysiological evidence for two distinct EPSPs. J Neurophysiol 61:607-620.

Thomson AM (1986) A magnesium sensitive post-synaptic potential in rat cerebral cortex resembles neuronal responses to $N$-methylaspartate. J Physiol (Lond) 370:531-549.

Valverde F, Facal-Valverde MV, Santacana M, Heredia M (1989) Development and differentiation of early generated cells of sublayer VIb in the somatosensory cortex of the rat: a correlated Golgi and autoradiographic study. J Comp Neurol 290:118-140.

Watkins JC, Evans RH (1981) Excitatory amino acid transmitters. Annu Rev Pharmacol Toxicol 21:165-204. 